\title{
Strategi Pengelolaan Paduan Suara Perguruan Tinggi: Studi Kasus Paduan Suara Mahasiswa Universitas Palangkaraya
}

\author{
Susiana Puspawatie \\ Program Magister Tata Kelola Seni, Program Pascasarjana ISI Yogyakarta \\ email: susiana.puspawatie@gmail.com
}

\begin{abstract}
Universitas Palangkaraya Student Choir, Central Kalimantan, has won various achievements at some championships held locally and internationally. This student activity unit (unit kegiatan mahasiswa, UKM) has been established since 1996 and has changed its management department every year. The purpose of this study was to determine the management strategy of the choir that is managed in the student activity unit at the university. For this reason, the formulation of the problem proposed in this study is how to apply management strategies in the Universitas Palangkaraya Choir Student Activity Unit? The results showed that there were 14 important principles applied by the choir at Universitas Palangkaraya to maintain its sustainability and existence. Based on the SWOT analysis, UKM Choir of Palangkaraya University has strengths in the spirit of togetherness, fairness and honesty, as well as order and discipline.
\end{abstract}

Keywords: student activity units, choir, management strategies.

\section{ABSTRAK}

Paduan Suara Mahasiswa Universitas Palangkaraya, Kalimantan Tengah, telah meraih berbagai macam prestasi pada berbagai kejuaraan yang diadakan di dalam maupun luar negeri. Unit Kegiatan Mahasiswa (UKM) ini sudah berdiri sejak tahun 1996 dan telah berganti kepegurusan setiap tahunnya. Tujuan dari penelitian ini adalah untuk mengetahui strategi pengelolaan manajemen Paduan Suara yang dikelola dalam sebuah Unit Kegiatan Mahasiswa di Universitas. Untuk itu rumusan masalah yang diajukan dalam penelitian ini adalah bagaimana menerapkan strategi pengelolaan manajemen dalam Unit Kegiatan Mahasiswa Paduan Suara Universitas Palangkaraya? Hasil penelitian menunjukan bahwa terdapat 14 prinsip penting diterapkan oleh paduan suara di Universitas Palangkaraya untuk menjaga keberlanjutan dan eksistensinya. Berdasarkan analisis SWOT, UKM Paduan Suara Universitas Palangkaraya memiliki kekuatan pada semangat kebersamaan, keadilan dan kejujuran, dan juga tertib dan disiplin.

Kata kunci: unit kegiatan mahasiswa, paduan suara, strategi pengelolaan. 


\section{PENDAHULUAN}

Organisasi itu merupakan sebuah kelompok atau komunitas yang memiliki sebuah visi, misi dan tujuan yang sama. Yang pada suatu ketika ada seseorang masuk didalam sebuah organisasi maka diapun wajib mengikuti proses dan aturan yang dibuat dalam organisasi tersebut. Dan untuk mencapai suatu tujuan bersama membutuhkan proses yang disebut strategi pengelolaan manajemen. Organisasi/kelompok/Unit Kegiatan Mahasiswa tanpa strategi pengelolaan manajemen sama saja dengan manusia yang tidak makan sama sekali tidak memiliki rencana, visi, misi dan tujuan hidup. Didalam sebuah organisasi itu pasti memiliki struktur organisasi. Misalnya saja seseorang yang mengikuti suatu organisasi adalah untuk mengembangkan kemampuan dari dirinya, didalam lingkungan Sekolah Menengah Pertama dan Sekolah Menengah Atas, siswa/murid biasanya diperkenalkan bentuk organisasi yang disebut OSIS. Sedangkan pada tingkat universitas/perguruan tinggi terdapat banyak organisasi mahasiswa, salah satunya disebut sebagai Unit Kegiatan Mahasiswa atau biasa disebut UKM.

Paduan Suara Universitas Palangkaraya adalah Unit Kegiatan Mahasiswa yang ada di Universitas Palangkaraya. Paduan Suara ini cukup eksis dan berprestasi dibandingkan dengan Unit Kegiatan Mahasiswa Universitas Palangkaraya yang lainnya. Unit Kegiatan Mahasiswa Paduan Suara Mahasiswa Universitas Palangkaraya telah dikenal di Indonesia terutama di Propinsi Kalimantan Tengah. Dari tahun ke tahun selalu mengukir prestasi di setiap kompetisi yang diikuti di luar negeri. Belakangan ini prestasi yang diraih oleh Paduan Suara Universitas Palangkaraya Kalimantan Tengah, antara lain; Medali emas pada kategori Mix Youth dan Folklore 2015 pada 3'rd Vietnam International Choir Competition di Hoi An, Vietnam. Hal yang luar biasa adalah keberhasilan menjadi Pemenang di Grand Prize Competiton pada 3'rd Vietnam International Choir Competition di tahun sama. Hasil Ini membuktikan bahwa UKM PSM Universitas palangkaraya tidak hanya mampu membanggakan institusinya namun juga membanggakan Indonesia di kancah internasional.

\section{KERANGKA ANALISIS}

Henry Fayol dalam General Industrial Management menyatakan manajemen adalah proses tertentu yang terdiri dari kegiatan merencanakan, mengorganisasikan, menggerakkan sumber daya manusia dan menggandakan pengendalian dalam 
rangka mencapai tujuan. Kemudian menurut (Handayaningrum, 2015:36) Terdapat Fungsi-fungsi manajemen yaitu 1) Perencanaan (Planning); 2) Pengorganisasian; 3) Koordinasi; 4) Monitoring; 5) Pengerakan; 6) pengawasan; 7) Penggalangan Dana (Fundraising). Fungsi-fungsi menejemen tersebut digunakan sebagai kerangka analisis pengelolaan paduan suara di Universitas Palangkaraya.

\section{PEMBAHASAN}

\section{Latar Belakang Berdirinya UKM Paduan Suara Universitas Palangkaraya}

Paduan Suara Universitas Palangkaraya merupakan Unit Kegiatan Mahasiswa yang bergerak dalam pengembangan bakat dan minat bidang seni vokal/suara. Didirikan pada tahun 1996 dengan nama Paduan Suara Mahasiswa UNPAR. Kemudian pada tahun 2015 berubah menjadi Paduan Suara Mahasiswa UPR. Paduan Suara Mahasiswa ini berfungsi sebagai wadah bagi mahasiswa untuk mengapresiasikan dan menyalurkan minat dan bakat olah vokal. Anggotanya merupakan mahasiswa yang berasal dari berbagai jurusan yang ada di Universitas Palangkaraya.

\section{Tujuan UKM Paduan Suara Universitas Palangkaraya}

Tujuan dari Unit Kegiatan Mahasiswa Paduan Suara Universitas Palangkaraya Kalimantan Tengah yaitu; "Meningkatkan Unit Kegiatan Mahasiswa Paduan Suara Mahasiswa Universitas Palangkaraya lebih maju, unggul, kreatif dalam bidang seni dan budaya". Berdasarkan dari uraian tersebut diatas UKM PSM UPR bertujuan untuk mendidik mahasiswa menjadi pribadi yang mandiri, berdisiplin tinggi, dan bertanggung jawab dalam kehidupan dan lingkungan kampus. Hal tersebut dimaknai bahwa ketika mahasiswa mengikuti organisasi, sedikit banyak akan membentuk karakter pribadi yang mandiri, disiplin tinggi, dan bertanggung jawab.

\section{Penerapan Strategi Pengelolaan Manajemen di Organisasi UKM Paduan Suara Universitas Palangkaraya}

Untuk sebuah keberhasilan dan kesuksesan diperlukan sebuah usaha atau kerjasama team dalam sebuah organisasi/kelompok. Di sini diperlukan strategi pengelolaan yang harus dilaksanakan berdasarkan prinsip-prinsip manajemen. Penulis akan membabarkan 7 prinsip dalam pembentukan sebuah organisasi Unit 
Kegiatan Mahasiswa Paduan Suara Universitas Palangkaraya Kalimantan Tengah, yang menurut prinsip-prinsip manajemen Henry Fayol yang mengemukakan ada 7 prinsip manajemen yang antara lain sebagai berikut:

Berikut pemaparan poin-poin tersebut:

1. Perencanaan (Planning)

Ada berbagai rangkaian kegiatan yang sudah direncanakan oleh Rio Natanael selaku ketua Paduan Suara Universitas Palangkaraya, yaitu :

- Di bulan Febuari - Maret biasanya diadakan seleksi tiap tahunnya

- Pada awal bulan April biasanyan akan ada diadakannya latihan perdana dari hasil audisi.

- Pada bulan Mei Paduan Suara Universitas Palangkaraya mengadakan latihan rutin serta memilih beberapa anggota Paduan Suara untuk mempersiapkan mengikuti event Pesparawi Mahasiswa tingkat nasional.

- Pada pertengahan bulan Mei juga, Paduan Suara Universitas Palangkaraya akan memilih juga beberapa anggota untuk persiapan Peksiminas untuk kategori vokal group, vokal solo putra/i (pop, keroncong, dangdut, seriosa).

- Pada bulan Agustus menampilkan beberapa lagu untuk memperingati hari Kemerdekaan dan juga pelayanan pujian di gereja-gereja.

2. Pengorganisasian (Organizing)

Proses pengorganisasian di Unit Kegiatan Mahasiswa Paduan Suara Mahasiswa Universitas Palangkaraya ada:

- Perincian pekerjaan

Demi tercapainya tujuan organisasi, yang pertama-tama harus ditentukan adalah tugas-tugas organisasi sebagai keseluruhannya. Hal ini semua sudah tertera pada AD dan ART Unit Kegiatan Mahasiswa Paduan Suara Universitas Palangkaraya, karena semua peraturan dan tujuan UKM Paduan Suara Universitas Palangkaraya sudah tertera didalamnya.

- Pembagian kerja

Pekerjaan organisasi haruslah dibagi dengan tepat diantara para anggotanya. Dengan istilah 'tepat' disini dimaksudkan pertama, anggota-anggota akan diserahkan tugas-tugas atas dasar kualifikasi mereka untuk tugas-tugas tersebut dan, kedua tak seorang pun akan dibebani tugas yang terlalu berat atau terlalu ringan untuk melakukannya. Untuk pemilihan divisi pengurus harian 
dan juga koordinator setiap divisi dipilih oleh ketua UKM Paduan Suara Universitas Palangkaraya. Untuk mengisi anggota masing-masiing tiap divisi, anggota dipersilahkan untuk menawarkan diri menjadi anggota yang disediakan, supaya apa yang dikerjakan sesuai dengan keinginan hatinya. Kemudian dipilih melalui vote atau perhitungan cepat melalui anggota yang lain.

- Penyatuan pekerjaan (departementalisasi)

Ketua Umum dan Pengurus Inti Paduan Suara Universitas Palangkaraya menjadi kepala didalam organisasi untuk menyampaikan tujuan organisasi Paduan Suara Universitas Palangkaraya sesuai arahan dari Pembina. Selanjutnya akan disampaikan pada tiap koordinator divisi yang sudah dibentuk untuk menyatukan visi, misi dan tujuan bersama.

\section{Koordinasi}

Pembatasan perintah atau yang disebut koordinasi di dalam UKM Paduan Suara Universitas Palangkaraya yaitu Pembina mengkoordinasikan kepada Pelatih dan juga Ketua UKM Paduan Suara Universitas Palangkaraya yang berikutnya Ketua UKM Paduan Suara Universitas Palangkaraya memberikan perintah kepada pengurus harian diantaranya; Ketua Bidang I, Ketua Bidang II, Bendahara I dan II juga kepada sekretaris 1 dan 2. Selanjutnya Ketua bidang satu memberikan informasi yang didapat oleh ketua umum kepada koordinator divisi Pelatihan, dan Pengembangan, dan juga Koordinasi Suara, begitu pula dengan Ketua Bidang dua menyampaikan informasi dari Ketua Umum kepada koordinator divisi Inventarisasi, Hubungan Masyarakat, dan juga Keanggotaan.

4. Monitoring dan reorganisasi.

Didalam hal ini peranan seorang Penasehat dan pembina UKM Paduan Suara Universitas Palangkaraya langsung Wakil Rektor Bidang Kemahasiswaan Prof. Dr. Ir. Bambang S. Lautt, M.Si dan Alumni, Pembina pak Adi Jaya sangatlah penting, selaku penasehat dan pembina beliau berdua selalu mengadakan evaluasi setiap pergantian periode untuk mengetahui dimana letak kekurangan dari setiap periode. Akan tetapi akhirnya secara tidak langsung yang selalu mengawasi seluruh anggota UKM Paduan Suara Universitas Palangkaraya adalah pelatihnya yaitu pak Andino Putra dan ibu Alderina Nahan. Reorganisasi dilaksanakan setiap setelah penerimaan mahasiswa baru di kampus Universitas Palangkaraya. 


\section{Penggerakan (Actuating).}

Penggerakan disini merupakan suatu seni dan penerapannya yang berhasil atau tidaknya tergantung dari pemikiran yang intensif, atau "pemberian motif" (motivating) kepada para anggota organisasi bahkan ada pula yang menganggap masalah penggerakan organisasi adalah masalah motivating belaka. Disini pelatih Andino Putra dan Alderina Nahan sangat berperan besar, karena didalam suatu organisasi yang bagus pasti terdapat seseorang yang dapat memberikan motivasi lebih untuk mendorong kemauan mencapai tujuan organisasi tersebut. Pembina tidak langsung dapat menggerakkan UKM Paduan Suara Universitas Palangkaraya dikarenakan Adi Jaya hanya mengawasi secara tidak langsung. Motivasi yang diberikan berupa semangat kebersamaan, kedisiplinan, dan juga tanggung jawab.

6. Pengawasan (Controlling)

Pada pengawasan atau Controlling ini, peranan dari Pembina UKM Paduan Suara Universitas Palangkaraya kepada Pelatih, Ketua Organisasi, dan Koordinator setiap divisi sangat berperan penting untuk menjaga pola pikir anggota supaya selalu mengingat dan melaksanakan tugasnya sesuai dengan bidang kerja masing-masing dalam mewujudkan tujuan utama dari organisasi UKM Paduan Suara Universitas Palangkaraya.

7. Penggalangan Dana (Fundraising)

Yang dimaksud disini yaitu tentang keberlanjutan dan rutinnya latihan sangat penting untuk bisa penggalangan dana, baik dari seluruh anggota Paduan Suara Universitas Palangkaraya, dari kampus Universitas Palangkaraya sendiri, maupun pihak luar yang mau menjalin hubungan dengan Paduan Suara Universitas Palangkaraya atau biasa disebut sponsorship dan juga donatur. UKM Paduan Suara Universitas Palangkaraya juga menggalang dana saat seleksi. Setiap Mahasiswa yang ingin mengikuti seleksi diwajibkan membayar administrasi sebesar Rp. 20.000,-. UKM Paduan suara Universitas Palangkaraya juga menggalang dana dari berbagai pelayanan dimana saja. Karena suatu hal yang sangat rahasia, peneliti tidak mendapatkan format keuangan dari UKM Paduan Suara Universitas Palangkaraya. 


\section{Pengelolaan Kegiatan Paduan Suara Universitas Palangkaraya}

Kegiatan atau latihan yang dilakukan Paduan Suara Universitas Palangkaraya diadakan dua kali dalam satu minggu dengan durasi waktu latihan selama 120menit $x$ 2 setiap $1 x$ proses latihan. Latihan diadakan pada hari selasa dan kamis, dimulai dari pukul 17.00 WIB hingga 19.00 WIB. Latihan akan segera dimulai bila anggota terkumpul sebanyak sepuluh Sopran, sepuluh Alto, lima Tenor, dan juga lima Bass. Namun apabila pukul 16.30 WIB anggota belum datang sejumlah Sopran, sepuluh Alto, lima Tenor, dan juga lima Bass, maka latihan akan tetap dilaksanakan berapapun jumlahnya.

Dandy, sebagai koordinator divisi latihan sangat berperan penting untuk mengingatkan kepada anggotanya untuk mengikuti latihan rutin setiap hari selasa dan kamis pukul 17.00 WIB untuk menumbuhkan rasa simpatik, disiplin dan tanggung jawab. Divisi latihan ini juga mengatur rundown apa saja yang harus dilakukan untuk pemanasan sebelum memulai latihan hingga latihan berpaduan suara dimulai, menentukan lagu yang akan digunakan untuk latihan, dan menentukan kapan latihan dapat dimulai juga dapat diakhiri.

\section{Sarana dan Prasarana Latihan}

Didalam sebuah manajemen organisasi pasti memiliki sarana dan prasarana untuk meningkatkan kualitas dari organisasi tersebut. Sarana dan prasarana yang dimaksud dalam organisasi ini adalah fasilitas yang tersedia untuk mengembangkan bakat dalam berpaduan suara sehingga dapat berdampak pada organisasi tersebut dan juga prestasi yang akan diraih. Tempat dan ruang untuk melakukan latihan paduan suara berada di Gereja Mahanaim atau aula Faperta yang berada di lingkungan Universitas Palangkaraya. Penataan ruang berlatih dilengkapi dengan tempat duduk yang setengah melingkar dan bertingkat, sedangkan didepan mahasiswa terdapat keyboard dan pelatih alat yang digunakan untuk membantu selama berproses. Ruang kesekretariatan Unit Kegiatan Mahasiswa Paduan Suara Universitas Palangkaraya terletak di Student Center lantai dua. Fasilitas yang dimiliki oleh kesekretariatan Unit Kegiatan Mahasiswa Universitas Palangkaraya yaitu kipas angin, lemari, meja dan kursi. 


\section{Dampak Positif pada Perkembangan Seluruh Anggota UKM Paduan Suara Universitas Palangkaraya}

Pendidikan musik dipercaya sebagai salah satu media yang dapat digunakan untuk mendidik atau membentuk karakter seseorang. Berkaitan dengan hal tersebut Gardner dalam Djohan (2003: 159) menyatakan bahwa,

"Kecerdasan musik merupakan bagian dari kecerdasan dasar manusia disamping kecerdasan logika, spasial, kinestetik, interpersonal, intrapersonal, dan spiitualistik. Intelegensi musical lebih banyak mengandung aspek emosi, spiritual dan budaya dari pada kecerdasan yang lain."

Dampak positif yang sangat terlihat pada setiap Individu didalam UKM Paduan Suara Universitas Palangkaraya yaitu kedisiplinan saat mengikuti latihan maupun setelah latihan diadakan, contohnya disiplin tepat waktu tanpa ikatan denda ataupun sangsi, selain disiplin waktu menjadikan setiap individu juga disiplin dalam tekhnik bernyanyi. Sedangkan contoh positif yang nampak diluar latihan yaitu terbentuknya etika dan perilaku yang baik, sopan dan ramah terhadap setiap orang yang ingin mengetahui tentang UKM Paduan Suara Universitas Palangkaraya.

\section{Analisis SWOT}

Unit Kegiatan Mahasiswa (UKM) merupakan kegiatan ekstrakurikuler atau aktivitas non-akademik yang ada dalam perguruan tinggi untuk melatih kemampuan atau keterampilan mahasiswa dalam suatu organisasi. Di dalam unit kegiatan mahasiswa (UKM) para mahasiswa bisa lebih bebas mengapresiasikan kegemarannya. Sebagai seorang mahasiswa, kita layak untuk memanfaatkan unit kegiatan mahasiswa (UKM) tersebut sebagai sarana pengembangan diri. Banyak manfaat yang akan kita dapatkan jika kita meluangkan waktu untuk belajar di UKM tersebut, tentunya sesuai minat kita. Sedangkan UKM ini juga bisa disebut sebuah Organisasiadalah suatu kelompok orang yang bekerja sama untuk tujuan bersama. Sedangkan secara terperinci pengertian organisasi adalah sebagai tempat atau wadah untuk orang berkumpuldan berkerja sama secara rasional dan sistematis, terencana, terpimpin, dan terkendali, dalam memanfaatkan sumber daya baik uang, metode, material, dan lingkungan, dan sarana-prasarana, data dan lain sebagainya yang digunakan secara efisen dan efektif untuk mencapai tujuan organisasi.

Berdasarkan fenomena yang ada di Unit Kegiatan Mahasiswa Paduan Suara Mahasiswa Universitas Palangkaraya, maka rumusan masalah yang akan diteliti 
yaitu: Bagaimana menerapkan strategi pengelolaan manajemen dalam Unit Kegiatan Mahasiswa Paduan Suara Universitas Palangkaraya dan untuk menjawab rumusan masalah tersebut maka peneliti menggunakan landasan teori strategi pengelolaan manajemen dengan pendekatan analisis SWOT. Di sini yang dimaksud dengan analisis SWOT adalah suatu bentuk analisis di dalam manajemen perusahaan atau di dalam organisasi yang secara sistematis dapat membantu dalam usaha penyusunan suatu rencana yang matang untuk mencapai tujuan, baik itu tujuan jangka pendek maupun tujuan jangka panjang. Atau definisi dari analisis SWOT antara lain yaitu sebuah bentuk analisa situasi dan juga kondisi yang bersifat deskriptif (memberi suatu gambaran). Analisa ini menempatkan situasi dan juga kondisi sebagai sebagai faktor masukan, lalu kemudian dikelompokkan menurut kontribusinya masing-masing. Satu hal yang perlu diingat baik-baik oleh para pengguna analisa ini, bahwa analisa SWOT ini semata-mata sebagai suatu sebuah analisa yang ditujukan untuk menggambarkan situasi yang sedang dihadapi, dan bukan sebuah alat analisa ajaib yang mampu memberikan jalan keluar yang bagi permasalahan yang sedang dihadapi. SWOT memiliki singkatan dari: $\mathrm{S}=$ Strength (kekuatan), $\mathrm{W}=$ Weaknesses (kelemahan), $\mathrm{O}=$ Opportunities (Peluang), $\mathrm{T}=$ Threats (Ancaman).

Dibawah ini akan peneliti jelaskan apa saja analisis swot dari UKM Paduan Suara Mahasiswa Universitas Palangkaraya, yaitu;

1. Strength (Kekuatan)

Faktor kekuatan adalah potensi diri yang bisa dikendalikan, artinya kalau faktor tersebut dieksploitasi dan dikembangkan maka akan menjadi khas dan nilai plus dari UKM Paduan Suara Universitas Palangkaraya. Tapi kalau tidak ada pengembangan maka nilai plus tersebut tidak akan bertambah, dan suatu saat bisa "dicuri" oleh organisasi lain yang mampu mengurus dan mengolah dengan lebih serius dan profesional. Faktor-faktor yang menjadi kekuatan UKM Paduan Suara Universitas Palangkaraya, antara lain :

- Memiliki Kualitas sumber daya manusia yang baik, dimulai dari pembina, pelatih dan juga anggota dari UKM Paduan Suara Universitas Palangkaraya.

- Memiliki Fasilitas relatif lengkap, seperti ruangan latihan yang memadai, peralatan dan perlengkapan latihan (keyboard/piano, serta sound), partitur, dan anggaran dana yang cukup untuk memenuhi kebutuhan organisasi.

- Lokasi kampus yang strategis. 
- Penggunaan teknologi dalam pengelolaan organisasi UKM Paduan Suara Mahasiswa

- Memiliki SOP dalam UKM Paduan Suara

2. Weaknesess (Kelemahan)

Kendala adalah halangan, rintangan atau kendala yang membatasi, menghalangi atau mencegah pencapaian sasaran, kekuatan yang memaksa pembatalan pelaksanaan (Tim Penyusun Kamus Besar Bahasa Indonesia, 2001 : 543)

Berdasarkan wawancara dengan Andino dan Alderina Nahan selaku pelatih Paduan Suara Universitas Palangkaraya kendala yang terdapat pada UKM Padaun Suara Universitas Palangkaraya yaitu :

- Sulitnya menentukan mahasiswa yang tepat dalam tempat yang tepat pula. Karena terkadang menemukan orang yang cocok dalam satu bagian karena memang sesuai dengan keahliannya, namun tidak mempunyai komitmen.

- Pengawasannya dari jajaran diatas kurang intens

- Karena dalam Paduan Suara Universitas Palangkaraya bergerak dalam bidang seni, mungkin terkadang proses birokrasi yang terlalu kaku seringkali menghambat progress organisasi itu sendiri.

- Masih belum bisa memenuhi semua target yang diinginkan pelatih

- Sasaran terbatas karena hanya yang tercatat sebagai mahasiswa/i

3. Oportunities (Peluang)

- Banyaknya apresiasi masyarakat terhadap seni terutama terhadap seni paduan suara di Palangkaraya khususnya, bisa dijadikan kegiatan-kegiatan untuk semakin sering diadakan.

- Meningkatnya permintaan semakin sering ditingkatkan kualitas pertunjukannya, sehingga mengakibatkan keterlibatan sebuah sponsorship dan juga donatur untuk menjadi lebih antusias dalam mensupport setiap kegiatan yang diselenggarakan oleh Unit Kegiatan Mahasiswa Paduan Suara Universitas Palangkaraya.

- Meningkatnya peminat mahasiswa/i yang ingin ikut bergabung tiap tahunnya.Threath (Ancaman)

- Faktor dari luar yang berpengaruh negatif terhadap perkembangan organisasi UKM Paduan Suara Universitas Palangkaraya, misalnya semakin berkembangnya kualitas organisasi UKM lain dengan segala ciri khasnya, akan 
menjadi ancaman serius setiap organisasi UKM untuk terus memperbaiki sistem organisasi, fasilitas, dan variasi kepelatihan untuk tidak menimbulkan rasa jenuh dan juga supaya organisasi UKM tersebut tetap bisa bertahan dan diminati oleh mahasiswa khususnya mahasiswa Universitas Palangkaraya.

4. Threats (Ancaman)

- Ancaman disini berasal faktor dari luar yang berpengaruh negatif terhadap perkembangan organisasi UKM Paduan Suara Universitas Palangkaraya, contohnya semakin berkembangnya kualitas dari organisasi UKM lain dengan segala ciri khasnya, bisa menjadi ancaman serius bagi setiap organisasi UKM untuk terus memperbaiki sistem organisasi, fasilitas, dan variasi kepelatihan untuk tidak menimbulkan rasa jenuh dan juga supaya organisasi UKM tersebut tetap bisa bertahan dan diminati oleh mahasiswa khususnya mahasiswa Universitas Palangkaraya.

- Tingginya persaingan antar UKM di lingkungan kampus sendiri dan juga kampus yang lain yang ada di sekitar Palangkaraya khususnya.

\section{SIMPULAN}

Berdasarkan hasil penelitian yang dilaksanakan oleh penulis tentang Manajemen Organisasi Unit Kegiatan Mahasiswa Paduan Suara Universitas Palangkaraya dapat diperoleh kesimpulan sebagai berikut: Prinsip dapat diartikan suatu komitmen yang dimiliki perorangan maupun sebuah organisasi kelompok. Terdapat 14 prinsip yang penting di dalam pembentukan sebuah organisasi UKM Paduan Suara Universitas Palangkaraya. Berdasarkan dari analisis SWOT, UKM Paduan Suara Universitas Palangkaraya memiliki kekuatan pada Semangat kebersamaan, keadilan dan kejujuran, dan juga Tertib dan disiplin. Namun UKM Paduan Suara Universitas Palangkaraya memiliki kelemahan pada wewenang dan tanggung jawab juga kesatuan perintah dan kesatuan arah, dikarenakan pada hakekatnya pembina yang memberikan perintah dan juga wewenangnya namun tidak diawasi secara langsung oleh pembina, melainkan melalui pelatih Andino Putra dan alderina Nahan yang belum tentu tersampaikan secara maksimal yang diinginkan oleh pembina UKM Paduan Suara Universitas Palangkaraya Prof. Dr. Ir. Bambang S. Lautt, M.Si dan Adi Jaya. 
Penerapan fungsi manajemen adalah adanya garis-garis yang jelas untuk mencapai tujuan, merupakan petunjuk bagi seluruh anggota organisasi, membantu memberi perhatian untuk mempertinggi praktek dan cara kerja para anggota, merupakan alat pengendali/mengawasi pelaksanaan, dan menghindarkan pemborosan. Fungsi manajemen dibagi menjadi 5 (lima). Berdasarkan analisis SWOT kelima fungsi manajemen tersebut mampu diterapkan dengan baik didalam organisasi UKM Paduan Suara Universitas Palangkaraya terkecuali pada pengawasan (controlling). Kelemahan UKM Paduan Suara Universitas Palangkaraya terletak pada pengawasan (controlling) dikarenakan pada hal ini pembina tidak mengawasi secara langsung bagaimana perkembangan dari UKM Paduan Suara Universitas Palangkaraya.

\section{DAFTAR PUSTAKA}

Handayaningrum, Warih. 2015. Manajemen Pertunjukan. Universitas Negeri Surabaya Press.

Fayol, Henry.1949. General Industrial Management. Pitman Publisher. London. Handoko, T. Hani. 1999, Manajemen Edisi 2. Yogyakarta : BPFE-Yogyakarta.

\section{Sumber Internet}

http://umum-pengertian.blogspot.com/2016/01/pengertian-manajemen-secaraumum-adalah.html, Date accessed: 11April 2019.

https://www.ngelmu.co/pengertian-organisasi/, Date accessed: 13 April 2019. http://www.pengertianku.net/2015/03/pengertian-analisis-swot-dan-manfaatnya.html, Date accessed: 13 April 2019. 